\title{
Theoretical Substantiation of the Angle of Mounting a Flat Ridge-Forming Disc of a Row Crop Cultivator
}

\author{
Evgeny Zykin ${ }^{1,}{ }^{*}$, Vladimir Kurdyumov ${ }^{1}$, and Svetlana Lazutkina ${ }^{1}$ \\ ${ }^{1}$ Department of Agrotechnologies, Machines and Life Safety, Ulyanovsk State Agrarian University, \\ Ulyanovsk, Russia
}

\begin{abstract}
The authors have developed a row-crop cultivator equipped with a ridge former, which allows performing high-quality operations of row crop cultivation in one pass. The inter row cultivation is carried out with a row-crop cultivator, on each section of which two ridge formers are mounted so that their flat discs are directed towards the row of plants at an acute angle, and the extreme edges of the wings of the V-shaped sweeps are located at the lower base of the soil ridge. When the row-crop cultivator moves, the $\mathrm{V}$-shaped sweeps loosen the soil to the required depth and cut the weeds, and the flat discs move the soil layer coming off the wings of the V-shaped sweeps towards the rows of plants, hilling them and burying the weeds. In the presented article, the authors theoretically substantiate the angle of attack of a flat disc for burying weeds with a layer of soil of the required thickness. It was found that the angle of attack depends on the radius of the flat disc and the depth of its movement in the soil, the initial dimensions of the ridge and the physical and mechanical properties of the soil.
\end{abstract}

\section{Introduction}

Cultivating row crops according to the traditional cultivation technology provides for two or three times of inter row cultivation with row-crop cultivators that have special working bodies or spraying with chemical solutions - herbicides. The width of the protective zone is

\footnotetext{
* Corresponding author: evg-zykin@yandex.ru
} 
increased with each subsequent tillage, as a result, the uncultivated area along the cultivated plants increases. The use of herbicides, in addition to the positive advantage - the elimination of weeds by $70 \ldots 80 \%$, has a negative side - a decrease in the yield of cultivated plants up to $15 \%[1,2,3,4,5,6]$.

\section{Objects and methods of research}

To eliminate the aforementioned disadvantages, the authors have devised a cultivation method [7] and technical means for row crop tending [8, 9, 10]. The proposed technical means provide loosening of the soil, destruction of weeds between rows and in protective zones along the rows of cultivated plants without the use of herbicides that cause great environmental contamination. With this method of crop tending, it is enough to perform one or two mechanized tillage operations of row spacings.

Row spacings are tilled with a special row-crop cultivator (Fig. 1), on each section of which two ridge-formers are mounted in such a way that their flat discs are directed towards the rows of cultivated plants at an acute angle (Fig. 2).

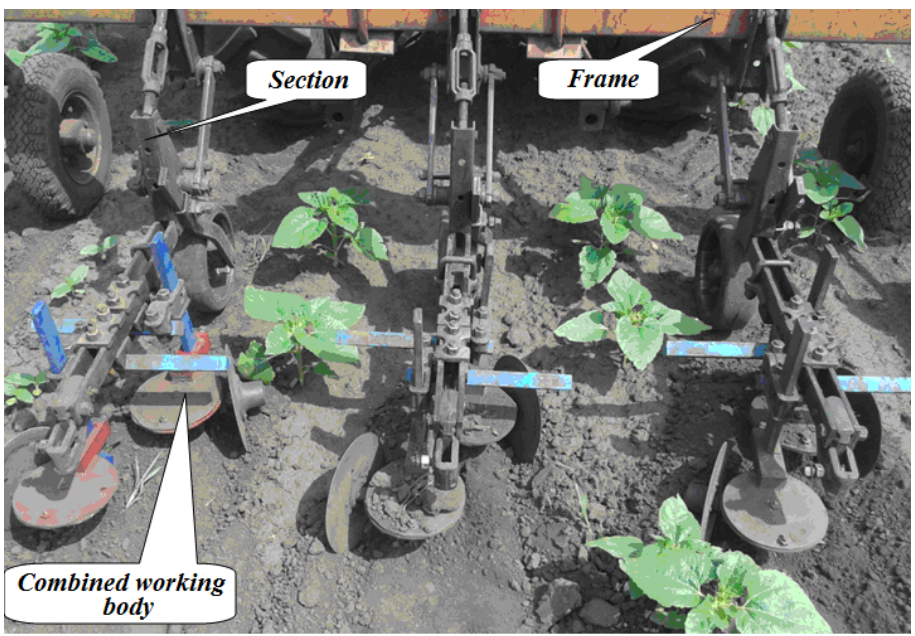

Fig. 1. Row-crop cultivator 


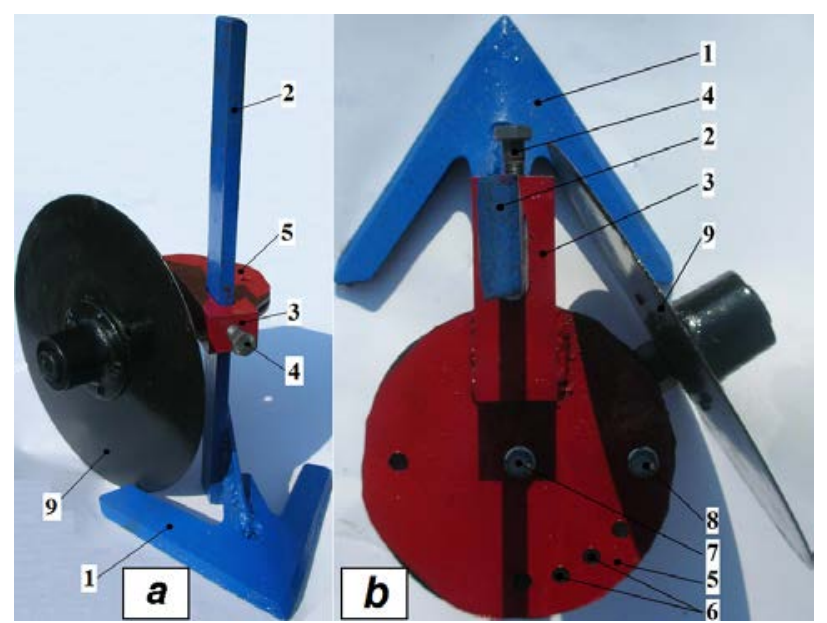

Fig. 2. Ridge former: a - general view; $b$ - top view; 1 - V-shaped sweep; 2 - shank; 3 - mounting bracket; 4 - clamping screw; 5 - an adjusting disk; 6 - holes; 7, 8 - bolts; 9 - flat disc

When the row-crop cultivator moves, the V-shaped sweeps 1 loosen the soil to the required depth and cut the weeds, and the flat discs 2 move the soil layer coming off the wings of the sweeps towards the rows of cultivated plants, thereby hilling cultivated plants and covering weeds.

\section{Research results}

Hilling of cultivated plants is carried out by pushing the soil volume $V_{l}, \mathrm{~m}^{3}$, with each flat disc (Fig. $3 a$ ) from the row spacing to the soil ridge. After the soil is moved to the top of the ridge, it partially falls down at an angle of natural slope of the soil ridge $\gamma$, deg., which, depending on the physical and mechanical properties of the soil, ranges from $26^{\circ}$ to $40^{\circ}$ (angle $\mathrm{B}_{1} \mathrm{~A}_{1} \mathrm{D}_{1}$ of the figure $\mathrm{A}_{1} \mathrm{~B}_{1} \mathrm{E}_{1} \mathrm{D}_{1}$ ). The thickness of the layer $h_{1}, \mathrm{~m}$, on the soil ridge depends on the angle of attack $\alpha$, deg., flat discs, as well as the depth $h, \mathrm{~m}$, their travel in the soil (Fig. 3b). 

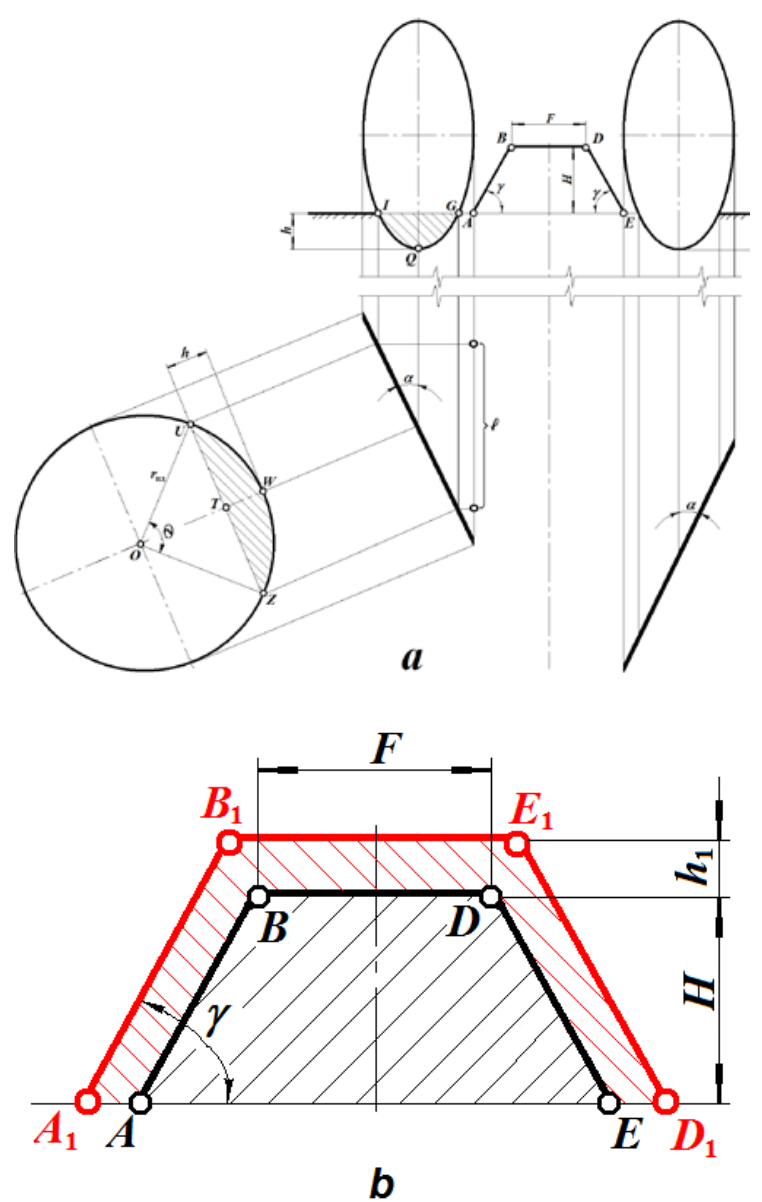

Fig. 3. Schemes of hilling $(a)$ and the profile of the soil layer moved on the ridge $(b)$

Summarizing the above calculations, we can conclude that for burying weeds and hilling cultivated plants, it is required that the volume of soil $V_{l}, \mathrm{~m}^{3}$, which should be moved to the original ridge of the soil, be equal to the volume of soil in the formed secondary ridge $V_{2}, \mathrm{~m}^{3}$,

$$
V_{1}=V_{2} \text {. }
$$

To determine the volume of soil $\mathrm{V}_{1}, \mathrm{~m}^{3}$, transferred to the top of the initial ridge formed by a flat disc, we use Fig. four. 


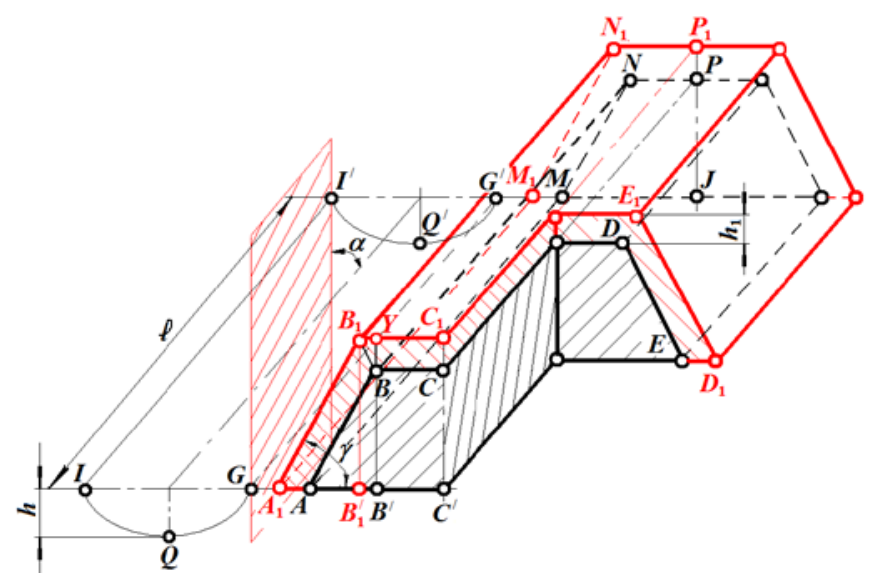

Fig. 4. Determination of the shifted volume of the soil depending on the angle of attack $\alpha$ of a flat disc

The volume of the soil, $\mathrm{m}^{3}$, shifted by one flat disc at the angle of attack $\alpha$,

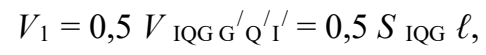

where $S_{\mathrm{IQG}}$ - cross-sectional area of the furrow formed after the passage of the working body of a ridge planter with a flat disc, $\mathrm{m}^{2}: \ell=G I^{\prime}$ - path travelled by a flat disc per unit of time, $\mathrm{m}$.

From Fig. $3 a$ it follows that the distance:

$$
\ell=U Z \cdot \cos \alpha
$$

where $U Z$ - chord of a flat disc, $m$.

The chord of a flat disc:

$$
U Z=2 r_{\text {пд }} \sin \frac{\theta}{2},
$$

where $r_{\text {пд }}$ - radius of a flat disc, $\mathrm{m}$.

Having substituted expression (4) in (3) we get:

$$
\ell=2 r_{\text {пд }} \sin \frac{\theta}{2} \cdot \cos \alpha .
$$

The area

$$
S_{\mathrm{IQG}}=S_{\mathrm{UWZ}} \cdot \sin \alpha,
$$

where $S_{\mathrm{UWZ}}$ - contact area of a flat disc with the soil, $\mathrm{m}^{2}$.

The contact area of a flat disc with the soil, $\mathrm{m}^{2}$,

$$
S_{\mathrm{UWZ}}=S_{\mathrm{OUWZ}}-S_{\mathrm{OUZ}},
$$

where $S_{\text {OUwZ }}$ - area of the flat disc sector, $\mathrm{m}^{2} ; S_{\mathrm{OUZ}}$ - area of the triangle $\Delta O U Z, \mathrm{~m}^{2}$. 
The area, $\mathrm{m}^{2}$, of the flat disc sector

$$
S_{\text {OUWZ }}=0,5 r_{\text {пд }}^{2} \frac{\theta}{360^{\circ}} .
$$

From Fig. $3 a$ it follows that the triangle $\triangle O U Z$ - is isosceles, consequently:

$$
\begin{gathered}
S_{\mathrm{OUZ}}=2 S_{\mathrm{OUT}}=2 \cdot 0,5 U T \cdot T O=U T \cdot T O . \\
U T=0,5 \mathrm{UZ}=0,5 \cdot 2 r_{\text {пд }} \sin \frac{\theta}{2}=r_{\text {пд }} \sin \frac{\theta}{2} . \\
T O=O W-T W=r_{\text {пд }}-h .
\end{gathered}
$$

Having substituted (10) and (11) into (9), we get

$$
S_{\text {OUZ }}=r_{\text {пд }} \sin \frac{\theta}{2}\left(r_{\text {пд }}-h\right) \text {. }
$$

Having substituted (8) and (12) into (7), we determine the area of contact of a flat disc with the soil:

$$
S_{\mathrm{UWZ}}=0,5 r_{\text {пд }}^{2} \frac{\theta}{360^{\circ}}-r_{\text {пд }} \sin \frac{\theta}{2}\left(r_{\text {пд }}-h\right) .
$$

Substituting (13) into (6), we determine the cross-section area of the furrow (Fig. 4):

$$
S_{\mathrm{IQG}}=\left[0,5 r_{\text {пд }}^{2} \frac{\theta}{360^{\circ}}-r_{\text {пд }} \sin \frac{\theta}{2}\left(r_{\text {пд }}-h\right)\right] \sin \alpha .
$$

By substituting expressions (5) and (14) into (2), and making the appropriate transformations, we obtain:

$$
V_{1}=\left[0,5 r_{\text {пд }}^{2} \frac{\theta}{360^{\circ}}-r_{\text {пд }} \sin \frac{\theta}{2}\left(r_{\text {пд }}-h\right)\right] \cdot 2 r_{\text {пд }} \sin \frac{\theta}{2} \sin \alpha \cdot \cos \alpha .
$$

The formed volume of the soil, $\mathrm{m}^{3}$,

$$
V_{2}=V_{\mathrm{A} 1 \mathrm{~B} 1 \mathrm{C} 1 \mathrm{CB} \text { AM N P1 N1 M1 }}=S_{\mathrm{A} 1 \mathrm{~B} 1 \mathrm{C} 1 \mathrm{CB} \mathrm{A}} \cdot C_{1} P_{1},
$$

where $S$ A1 B1 C1 C B A - cross-section area of the soil layer made by one flat disc, $\mathrm{m}^{2}$, (Fig. 4); $\quad C_{1} P_{1}=I I^{\prime}, \mathrm{M}$.

From Fig. 4 it follows that $I I^{\prime}=\ell$. In view of expression (5)

$$
C_{1} P_{1}=I I^{\prime}=\ell=2 r_{\text {пд }} \sin \frac{\theta}{2} \cdot \cos \alpha .
$$

The area $S_{\mathrm{A} 1 \mathrm{~B} 1 \mathrm{C1} \text { C B A }}$ to be sought we will determine in the following way:

$$
S_{\mathrm{A} 1 \mathrm{~B} 1 \mathrm{C} 1 \mathrm{CB} \mathrm{A}}=S_{\mathrm{A} 1 \mathrm{~B} 1 \mathrm{Cl} \mathrm{C}^{\prime} \mathrm{A} 1}-S_{\mathrm{AB} \mathrm{BCC}^{\prime}} \text {, }
$$

where $S_{\mathrm{A} 1 \mathrm{~B} 1 \mathrm{Cl} \mathrm{C}^{\prime} \mathrm{A} 1}-$ area of a half of the cross-section of the secondary soil ridge, $\mathrm{m}^{2}$; $S_{\text {A B C C }}{ }^{\prime}$ - area of a half of the cross-section of the initial soil ridge, $\mathrm{m}^{2}$.

We will represent the area $S_{\mathrm{A} 1 \mathrm{~B} 1 \mathrm{Cl} \mathrm{C}^{\prime}}$ A1 in the form of two areas - a triangle and a rectangle:

$$
S_{\mathrm{A} 1 \mathrm{~B} 1 \mathrm{C} 1 \mathrm{C}^{\prime} \mathrm{A} 1}=S_{\mathrm{A} 1 \mathrm{~B} 1 \mathrm{~B} 1} /+S_{\mathrm{B} 1} /{\mathrm{B} 1 \mathrm{C} 1 \mathrm{C}^{\prime}}^{\prime}
$$

The area of a triangle, $\mathrm{m}^{2}$, 


$$
S_{\mathrm{A} 1 \mathrm{~B} 1 \mathrm{~B} 1} /=\frac{B_{1} B_{1}^{\prime} \cdot A_{1} B_{1}^{\prime}}{2},
$$

where $B_{1} B_{1}{ }^{\prime}=H+h_{1}, \mathrm{~m} ; H$ - height of the initial soil ridge, $\mathrm{m}$.

$$
A_{1} B_{1}{ }^{\prime}=B_{1} B_{1}{ }^{\prime} \operatorname{tg} \gamma=\left(H+h_{1}\right) \operatorname{tg} \gamma .
$$

By substituting (21) into (20), and, having made the corresponding transformations, we obtain:

$$
S_{\mathrm{A} 1 \mathrm{~B} 1 \mathrm{~B} 1} /=\frac{\left(H+h_{1}\right)^{2} \operatorname{tg} \gamma}{2} .
$$

The area of a rectangle, $\mathrm{m}^{2}$,

$$
S_{\mathrm{B} 1 / \mathrm{B}_{1 \mathrm{C} 1 \mathrm{C}}{ }^{\prime}=B_{1} B_{1}{ }^{\prime} \cdot B_{1} C_{1} .}
$$

From Fig. 4 it follows that

$$
B_{1} C_{1}=B_{1} Y+Y C_{1}=\frac{h_{1}}{\operatorname{tg} \gamma}+\frac{F}{2}
$$

where $F$ - width of the top of the soil ridge, $\mathrm{m}$.

Substituting the obtained value in (23) and performing the appropriate transformations, we get:

$$
S_{\mathrm{B} 1 / \mathrm{B}_{\mathrm{C} 1 \mathrm{C}}{ }^{\prime}=} \frac{h_{1}\left(H+h_{1}\right)}{\operatorname{tg} \gamma}+\frac{F}{2} .
$$

Substituting (22) and (25) into (19), and by performing the appropriate transformations, we obtain:

$$
S_{\mathrm{A} 1 \mathrm{~B} 1 \mathrm{C} 1 \mathrm{C}^{\prime} \mathrm{A} 1}=\frac{\left(H+h_{1}\right)^{2} \operatorname{tg} \gamma}{2}+\left(H+h_{1}\right)\left(\frac{h_{1}}{\operatorname{tg} \gamma}+\frac{F}{2}\right) .
$$

We will represent the area $S_{\mathrm{A} \mathrm{B} \mathrm{C} \mathrm{C}}{ }^{\prime}$ in the form of two areas - a triangle and a rectangle:

$$
S_{\mathrm{ABCC}}{ }^{\prime}=S_{\mathrm{AB} \mathrm{B}} /+S_{\mathrm{B}} / \text { в CC }^{\prime} \text {. }
$$

The area of the triangle, $\mathrm{m}^{2}$,

$$
S_{\mathrm{AB} \mathrm{B} \mathrm{B}} /=\frac{B B^{\prime} \cdot A B^{\prime}}{2},
$$

where $B B^{\prime}=H$, м.

$$
A B^{\prime}=B B^{\prime} \operatorname{tg} \gamma=H \operatorname{tg} \gamma
$$


After substituting (29) into (28), and corresponding transformations, we will obtain:

$$
S_{\mathrm{A} 1 \mathrm{~B} 1 \mathrm{C1} \text { C B A }}=\frac{\left(H+h_{1}\right)^{2} \operatorname{tg} \gamma+2\left[\left(H+h_{1}\right)\left(\frac{h_{1}}{\operatorname{tg} \gamma}+\frac{F}{2}\right)\right]-H(H \operatorname{tg} \gamma+F)}{2} .
$$

Substituting (30) and (17) in (16), and performing the appropriate transformations, we determine the volume of soil, $\mathrm{m}^{3}$, obtained after moving it to the ridge with one disc:

$$
V_{2}=\left\{\left(H+h_{1}\right)^{2} \operatorname{tg} \gamma+2\left[\left(H+h_{1}\right)\left(\frac{h_{1}}{\operatorname{tg} \gamma}+\frac{F}{2}\right)\right]-H(H \operatorname{tg} \gamma+F)\right\} r_{\text {пд }} \sin \frac{\theta}{2} \cdot \cos \alpha .
$$

To determine the required angle of attack $\alpha$, deg., of a flat disc, we equate expression (15) to (31):

$$
\begin{gathered}
{\left[0,5 r_{\text {пд }}^{2} \frac{\theta}{360^{\circ}}-r_{\text {пд }} \sin \frac{\theta}{2}\left(r_{\text {пд }}-h\right)\right] \cdot 2 r_{\text {пд }} \sin \frac{\theta}{2} \sin \alpha \cdot \cos \alpha=} \\
=\left\{\left(H+h_{1}\right)^{2} \operatorname{tg} \gamma+2\left[\left(H+h_{1}\right)\left(\frac{h_{1}}{\operatorname{tg} \gamma}+\frac{F}{2}\right)\right]-H(H \operatorname{tg} \gamma+F)\right\} r_{\text {пд }} \sin \frac{\theta}{2} \cdot \cos \alpha .
\end{gathered}
$$

Making transformations of equation (32), we will determine the angle of attack of a flat disc:

$$
\alpha=\arcsin \frac{\left\{\left(H+h_{1}\right)^{2} \operatorname{tg} \gamma+2\left[\left(H+h_{1}\right)\left(\frac{h_{1}}{\operatorname{tg} \gamma}+\frac{F}{2}\right)\right]-H(H \operatorname{tg} \gamma+F)\right\}}{2\left[0,5 r_{\text {пд }}^{2} \frac{\theta}{360^{\circ}}-r_{\text {пд }} \sin \frac{\theta}{2}\left(r_{\text {пд }}-h\right)\right]} .
$$

\section{Conclusion}

Thus, to create a secondary ridge with the required thickness of the soil layer $h_{1}$, it is necessary to mount a flat disc at an angle of attack $\alpha$, which, given the dimensions of the initial soil ridge $F$ and $H$ and the angle of natural slope of the soil $\gamma$, depends on the radius of the flat disc $r_{\text {пд }}$ and the depth of its travel in the soil $h$.

The project is carried out within the framework of the grant of the President of the Russian Federation for state support of young Russian scientists - Doctors of Science MD-2259.2020.8.

\section{References}

1. Zykin, E. Process modeling of the first interrow cultivation in laboratory conditions / Evgeny Zykin, Vladimir Kurdyumov, Svetlana Lazutkina, Oleg Dmitriev // E3S Web of Conferences 193, 01041 (2020). ICMTMTE 2020. 
2. Zykin, E. The experimental determination of the diameter of a flat disc in a ridge seeder / Evgeny Zykin, Vladimir Kurdyumov, Svetlana Lazutkina, Sergey Albutov // IOP Conf. Series: Ma-terials Science and Engineering 971 (2020) 052055. ICMTMTE 2020.

3. Zykin, E. Modeling of the sowing process of row crops in laboratory conditions / Evgeny Zykin, Vladimir Kurdyumov, Sergey Albutov, Oleg Dmitriev // E3S Web of Conferences 193, 01040 (2020). ICMTMTE 2020.

4. Erzamaev, M.P. Improving the efficiency of using arable machines / M.P. Erzamaev, D.S. Sazonov, E.O. Salomatov // Innovative achievements of science and technology of the agro-industrial complex: collection of scientific papers of the International scientific and practical conference. - Kinel: Samara State Agricultural Academy, 2017.pp. 689-692.

5. Akramkhanov, A. Technology of planting crops along the ridges / A. Akramkhanov // TECHNOLOGIES \& BEST PRACTICES FACTSHEET. - URL: http://www.cacilm.org/articles/detail/493 (access date 05/09/2021).

6. Pat. 2443094 Russian Federation, IPC A01B79 / 02, A01G1 / 00. Method of cultivation of row crops / V.I. Kurdyumov, E.S. Zykin; applicant and patentee FSEI HPE "Ulyanovsk State Agricultural Academy". - No. 2010141211/13; applied for 10/07/2010; publ. 27.02.2012, Bul. No. 6.

7. Pat. 2507730 Russian Federation, IPC A01B39 / 18. Row-crop cultivator / V.I. Kurdyumov, E.S. Zykin; applicant and patentee FSBEI HPE Ulyanovsk State Agricultural Academy named after P.A. Stolypin ". - No. 2012137736/13; applied for 04.09.2012; publ. 02.27.2014, Bul. No. 6.

8. Pat. 2507729 Russian Federation, MPK A01B35 / 00. Row-crop cultivator / V.I. Kurdyumov, E.S. Zykin; applicant and patentee FSBEI HPE Ulyanovsk State Agricultural Academy named after P.A. Stolypin ". - No. 2012136083/13; applied for 08.21.2012; publ. 02.27.2014, Bul. No. 6.

9. Pat. 2464755 Russian Federation, MPK A01B35 / 16, A01B35 / 18. A01B39 / 20. The working body of the cultivator / V.I. Kurdyumov, E.S. Zykin, I.A. Sharonov; applicant and patentee FSBEI HPE "Ulyanovsk State Agricultural Academy". - No. 2011145008/13; applied for 11/07/2011; publ. 27.10.2012, Bul. No. 30.

10. Kurdyumov, V.I. Substantiation of the angle of attack for the flat disc of the working body of the ridge roller seeder / V.I. Kurdyumov, E.S. Zykin // Bulletin of the Ulyanovsk State Agricultural Academy. - 2012. - No. 4 (20). - pp. 127 - 130. 